\title{
Analysis of Economic Sustainable Growth Based on Economic Ethics System Model
}

\author{
Yiyan Chen ${ }^{1}$ and $\mathrm{Ye} \mathrm{Li}^{2, \mathrm{a}}$ \\ ${ }^{1}$ Beijing Institute of Technology, School of Automation, 100081 Beijing, China \\ ${ }^{2}$ Chinese Academy of Social Sciences, Institute of Quantitative \& Technical Economics, 100732 Beijing, China
}

\begin{abstract}
The economic ethics is an abstract variable in economic system, and there is a correlation between the economic ethics and the sustainable economic growth. First of all, the existing researches are discussed from the macro perspective. On this basis, a set of economic ethics system is constructed. Afterwards, from the micro perspective, the necessary conditions for the growth of sustainable economics are obtained through the positive and negative benefit functions of the three dimensions of the government economic ethics, the enterprise economic ethics and the personal economic ethics under the condition of whether to abide by the law and whether to abide by ethics. Finally, the whole economic ethics system is analyzed and the conclusion is obtained that violating the economic ethics will hinder the sustainable growth of economy, while obeying the economic ethics will promote the sustainable growth of economy.
\end{abstract}

\section{Definition of economic ethics}

The term "economic ethics" is firstly put forward by Max Weber in "Economic Ethics of World Religion". It is an interdisciplinary subject which belongs to philosophy and economics. As the name implies, the economic ethics is a series of ethical principles and moral norms that directly adjust and regulate the economic activities of people. The economic ethics is a discipline to study the ethical and moral problems in economy. There are three ways to understand the category of economic ethics in Chinese academic circles: the economic ethics, the ethical economics and the economy and ethics. Gong Tianping, a professor at Zhongnan University of Economics and Law, believes that the economic ethics is a kind of ethical and moral concept, norm and practice activity in human economic relation communication. The connotation of the economic ethics can be divided into three aspects: the consciousness of economic ethics, the norms of economic ethics and the practice of economic ethics ${ }^{[1]}$. The consciousness of economic ethics refers to the moral legitimacy (justice, rationality and authenticity, etc.) consciousness of the economic subject in the economic relations. The norms refer to the moral norms that the economic subjects should abide by in their economic behaviors, including the moral principles and the codes of moral conduct. The practice refers to the moral choices made by the economic subjects in the face of difficult moral problems or dilemmas. The organic combination of the three aspects is the connotation of the economic ethics.

a Corresponding author: townjam_sovietnia@163.com

\section{Relationship between the economic ethics and the sustainable economic growth}

Under the background of global economic integration, the sustainable economic growth has become a necessary condition for the development of human society. Many scholars are studying the economic growth and putting the research results into practice in human society. The economics are divided into various branches according to different emphases. However, there are so-called economic assumptions in any branch of economics, including the rational man hypothesis, the scarcity hypothesis, the non-satisfaction hypothesis, the complete information hypothesis, the market clearing hypothesis, the natural selection hypothesis and the invariant preference hypothesis, etc. The most common hypothesis used in various branches of economics is the rational man hypothesis. The rational man hypothesis believes that all human behaviors are to satisfy their own interests to the maximum ${ }^{[2]}$. However, in the practice of promoting the economic growth, many people tend to one-sidedly believe that the economic growth determines everything, that is, the excessive and one-sided interpretation of the rational man hypothesis as well as the ignorance of the importance of economic ethics in order to achieve the purpose of economic growth results in the wrong way of development that the short-term economic growth replaces the long-term economic growth. In addition, some people think that there is a dichotomy between the rational man hypothesis and the economic ethics and this view is also not correct ${ }^{[3]}$. Many studies have shown that 
the market with good economic ethics can promote sustainable economic growth ${ }^{[4-7]}$.

\subsection{The three dimensions covered by the economic ethics}

According to the different nature of the market participants, the economic ethics can be divided into three dimensions: the government economic ethics, the enterprise economic ethics and the individual economic ethics. The three aspects depend on each other. The government, the enterprise and the individuals supervise each other's economic ethics. The characteristics are shown in Table 1.

Table 1. Three dimensions of economic ethics

\begin{tabular}{|c|c|c|c|}
\hline $\begin{array}{c}\text { Dimension } \\
\text { name }\end{array}$ & Object & $\begin{array}{c}\text { Ethics } \\
\text { Size }\end{array}$ & $\begin{array}{c}\text { Related } \\
\text { objects }\end{array}$ \\
\hline $\begin{array}{c}\text { Government } \\
\text { economic ethics }\end{array}$ & Government & Macro & $\begin{array}{c}\text { Enterprise, } \\
\text { Individual }\end{array}$ \\
\hline $\begin{array}{c}\text { Enterprise } \\
\text { economic ethics }\end{array}$ & Enterprise & Micro & $\begin{array}{c}\text { Government, } \\
\text { Individual }\end{array}$ \\
\hline $\begin{array}{c}\text { Individual } \\
\text { economic ethics }\end{array}$ & Individual & Micro & $\begin{array}{c}\text { Government, } \\
\text { Enterprise }\end{array}$ \\
\hline
\end{tabular}

\subsubsection{Government economic ethics and sustainable economic growth}

The government is the top force in economic development. As the main responsible part of the macroeconomic regulation and control, the government should have a universal moral practice subject consciousness and respect the subject value of every economic actor under its governance. The market regulation under the government should be combined with the policy control, and the decisions made by the government should play more important roles in the policy control. A good economic policy should give consideration to the equity when giving priority to the efficiency so that the working people can enjoy the dividends of development. Formulating a good economic policy is the core connotation of the government economic ethics. Only the good economic policies can consider the people-oriented development and achieve a comprehensive balance between incentives and stability, innovation and prudence, private property and social responsibility, power and supervision, efficiency and fairness, common development and individual rights and interests. At the same time, the endogenous stability of the economy can be also promoted and the momentum of the sustained economic growth can be enhanced.

\subsubsection{Enterprise economic ethics and sustainable economic growth}

The enterprise is the backbone of the economic development. It should not have a single economic purpose, but should also give consideration to the social benefits. The social responsibility of enterprises is the core connotation of the enterprise economic ethics. Similar to the three dimensions of the economic ethics, the social responsibility of enterprises also has three ethical dimensions: historicity, humanism and fairness. The social responsibility of enterprises cannot be separated from the development process of specific history. It must be discussed in combination with different historical and economic system background, which is the historical dimension of social responsibility of enterprises The ultimate goal of enterprise development is to act on people themselves and the development of enterprises needs the human participation. The ultimate goal of the development is also for the people themselves. Maintaining the legitimate rights and interests of the employees, helping the disadvantaged groups and observing the market order are the humanism dimension of corporate social responsibility. While pursuing the economic development and the corporate economic interests, it is required to fairly treat the status of people and things in the development of enterprises, fairly treat all stakeholders of the enterprises and fairly share the fruits of enterprise development with members of the society. It is the fairness dimension of the corporate social responsibility. Only by adhering to the social responsibility, can the development of the enterprises get the approval and the support of the whole social environment and the market participants. The enterprises can have the economic soil for development. If all enterprises can bear the social responsibility, the economic growth brought by enterprises will be sustainable.

\subsubsection{Individual economic ethics and sustainable economic growth}

The individual is the basic force of the economic development. The individual economic ethics is a kind of moral restriction that the individual combines the economic ethics with the individual ethics on the basis of abiding by the law through taking into account the moral criterion while pursuing the maximization of the personal interests. Then, a kind of moral restriction on the behaviors can be produced. The individual is the terminal participant in the whole economic chain. Whether the individual adheres to the economic rules or not will directly affect the efficiency of enterprises and the decision-making of government. If everyone restricts themselves through the personal economic ethics and provides a good ethical order for the whole economic environment, the economic growth will be sustainable.

\subsection{Establishment of the economic ethics system}

The government economic ethics, the enterprise economic ethics and the individual economic ethics should be mutually monitored to form a solid triangular structure to prevent the collapse of the economic ethics in one corner. The mutual supervision among the three aspects plays a positive role in the benefit of the sustainable economic growth. At the same time, the benefits of the unsustainable economic growth can have a negative effect on the economic ethics and induce the economic participants to violate the economic ethics. The 
relationship between these two kinds of interests is mutually influenced and gambled. It needs to have a quantitative model to carry on the model test, thus feedback the test results to the government, the enterprises and the individuals. Afterwards, they can improve and correct their economic ethics in time. In this way, a theoretical model between the economic ethics and the sustainable economic growth can be established, as shown in Figure 1.

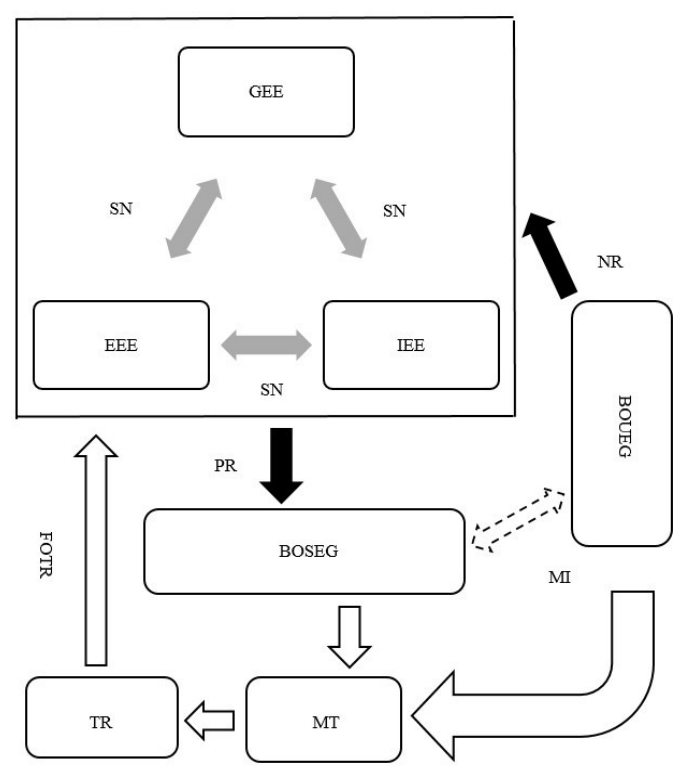

Figure 1. Systematic chart of the economic ethics and the sustainable economic growth.

The meaning of abbreviations in figure are as follows: GEE: Government economic ethics. SN: Supervision. EEE: Enterprise economic ethics. IEE: Individual economic ethics. PR: Positive role. NR: Negative role. FOTR: Feedback of test results. TR: Test results. BOSEG: Benefits of sustainable economic growth. MT: Model test. MI: Mutual influence. BONEG: Benefits of unsustainable economic growth.

\section{Analysis of the sustainable economic growth under the economic ethics system}

$$
\begin{aligned}
E & =\sum_{i=1}^{3}\left[M\left(X_{i}\right)\right]\left[1-P_{i}\left(X_{i}\right)\right] \\
& +\sum_{i=1}^{3}\left[N\left(T_{i}\right)\right]\left[1-Q_{i}\left(T_{i}\right)\right] \\
& -\sum_{i=1}^{3} X_{i} \cdot P_{i}\left(X_{i}\right)-\sum_{i=1}^{3} T_{i} \cdot Q_{i}\left(T_{i}\right) \\
& +\sum_{i=1}^{3} \mu_{i}+\sum_{i=1}^{3} \pi_{i}
\end{aligned}
$$

$E$ is the expected benefits of the unsustainable economic development, $X_{i}$ is the economic cost of violating the law, $T_{i}$ is the moral cost of violating the economic ethics, $M\left(X_{i}\right)$ is the economic benefits of violating the law, $N\left(T_{i}\right)$ is the moral benefits of violating the economic ethics, $P_{i}\left(X_{i}\right)$ is the behavior transparency of violating the law, $Q_{i}\left(T_{i}\right)$ is the behavior transparency of violating the economic ethics, $\mu_{i}$ is the random error of the economic cost of violating the law and $\pi_{i}$ is the random error of the moral cost of violating the economic ethics.

$$
\begin{aligned}
F & =\sum_{i=1}^{3}\left[M\left(Y_{i}\right)\right]\left[1+P_{i}\left(Y_{i}\right)\right] \\
& +\sum_{i=1}^{3}\left[N\left(S_{i}\right)\right]\left[1+Q_{i}\left(S_{i}\right)\right] \\
& -\sum_{i=1}^{3} Y_{i}\left[1-P_{i}\left(Y_{i}\right)\right]-\sum_{i=1}^{3} S_{i}\left[1-Q_{i}\left(S_{i}\right)\right] \\
& +\sum_{i=1}^{3} v_{i}+\sum_{i=1}^{3} v_{i}
\end{aligned}
$$

$F$ is the expected benefits of the sustainable economic development, $Y_{i}$ is the economic cost of complying with the law, $S_{i}$ is the moral cost of abiding by the economic ethics, $M\left(Y_{i}\right)$ is the economic benefits of complying with the law, $N\left(S_{i}\right)$ is the moral benefits of abiding by the economic ethics, $P_{i}\left(Y_{i}\right)$ is the behavior transparency of complying with the law, $Q_{i}\left(S_{i}\right)$ is the behavior transparency of abiding by the economic ethics, $v_{i}$ is the random error of the economic cost of complying with the law and $v_{i}$ is the random error of the moral cost of abiding by the economic ethics.

For the economic body (government, enterprise or individual) that complies with the law, the information transparency has a positive amplification effect on its economic benefits, that is $P_{i}\left(Y_{i}\right) \uparrow$, then $1+P_{i}\left(Y_{i}\right) \uparrow$. The ultimate economic benefit is $\sum_{i=1}^{3}\left[M\left(Y_{i}\right)\right]\left[1+P_{i}\left(Y_{i}\right)\right] \uparrow$. For the economic body that complies with the law, the higher the information transparency is, the higher the ultimate economic benefits will be. Similarly, for the economic body that complies with the law, the information transparency has a negative narrowing effect on its economic costs, $P_{i}\left(Y_{i}\right) \uparrow$, then $1-P_{i}\left(Y_{i}\right) \downarrow$. The ultimate economic cost is $\sum_{i=1}^{3} Y_{i}\left[1-P_{i}\left(Y_{i}\right)\right] \downarrow$. For the economic body that complies with the law, the higher the information transparency is, the lower the ultimate economic cost will be. Finally, for the economic body that complies with the law, the higher the information transparency is, the higher the net surplus income of the economy will be. When $P_{i}\left(Y_{i}\right) \uparrow$, it is clear that: 


$$
\sum_{i=1}^{3}\left[M\left(Y_{i}\right)\right]\left[1+P_{i}\left(Y_{i}\right)\right]-\sum_{i=1}^{3} Y_{i}\left[1-P_{i}\left(Y_{i}\right)\right] \uparrow
$$

For the economic body (government, enterprise or individual) that adheres to the economic ethics, the information transparency will have a positive amplification effect on its moral benefits, $Q_{i}\left(S_{i}\right) \uparrow$, then $1+Q_{i}\left(S_{i}\right) \uparrow$. The ultimate moral benefit is $\sum_{i=1}^{3}\left[N\left(S_{i}\right)\right]\left[1+Q_{i}\left(S_{i}\right)\right] \uparrow$. For the economic body that abides by the economic ethics, the higher the information transparency is, the higher the ultimate moral benefits will be. Similarly, for the economy body that adheres to the economic ethics, the information transparency has a negative narrowing effect on its moral costs, $Q_{i}\left(S_{i}\right) \uparrow$, then $1-Q_{i}\left(S_{i}\right) \downarrow$. The ultimate moral cost is $\sum_{i=1}^{3} S_{i}\left[1-Q_{i}\left(S_{i}\right)\right] \downarrow$. For the economic body that adheres to the economic ethics, the higher the information transparency is, the lower the ultimate moral cost will be. Finally, for the economic body that abides by the economic ethics, the higher the information transparency is, the higher the ultimate moral net income will be. When $Q_{i}\left(S_{i}\right) \uparrow$, it is clear that:

$$
\sum_{i=1}^{3}\left[N\left(S_{i}\right)\right]\left[1+Q_{i}\left(S_{i}\right)\right]-\sum_{i=1}^{3} S_{i}\left[1-Q_{i}\left(S_{i}\right)\right] \uparrow
$$

Similarly, for the expected benefits of the unsustainable economic development, $P_{i}\left(X_{i}\right) \uparrow$, $Q_{i}\left(T_{i}\right) \uparrow$, then $E \downarrow$.

\section{Conclusion}

Assuming $U=F-E, U$ is the comprehensive benefits of the sustainable economic development. Obviously, if
$P_{i}\left(Y_{i}\right) \uparrow$ and $Q_{i}\left(S_{i}\right) \uparrow$, then $F \uparrow$ and $U \uparrow$. As long as the economy body obeys the law and adheres to the economic ethics, its development is sustainable. The higher the information transparency is, the higher the expected benefits of the sustainable economic development will be and the greater the potential for the sustainable economic growth will be. It is known that the economic ethics has a positive role in promoting the sustained growth of economy. The economic growth will be sustained when abiding by the economic ethics. The economic growth will not be sustained if it goes against the economic ethics.

\section{References}

1. Gong Tianping, Li Haiying. A Reflection on the Connotation of Economic Ethics --- The Unification of Consciousness, Norm and Practice [J/OL]. Journal of Zhongnan University of Economics and Law, 2013, (01): 24-30+158.

2. Herbert Gintis. Game Theory Evolving: A Problem-Centered Introduction to Modeling Strategic Interaction (Second Edition) [M]. Beijing: China Renmin University Press, 2015.

3. Gong Tianping. How to Enter the Economic Ethics for Environmental Protection [J]. Studies in Ethics, 2013, (04): 84-89.

4. Han Xiping, Wang Lixin. The Supreme Law of Contemporary Economic Ethics: The Rule of Sustainability [J]. Journal of Nanjing Normal University (Social Sciences Edition), 2017 (01): 21-26.

5. Zhou Dan. Moral Economy: Proper Theme of the Study of Contemporary Economic Ethics [J]. Studies in Ethics, 2017 (04): 126-131.

6. Zheng Liansheng. Sharing Economy: Essence, Mechanism, Models and Risks [J]. International Economic Review, 2017 (06): 45-69+5.

7. Dawa Tsering. On the Current Status and Future Potential of Tibet's Ecological Economics [J]. Tibetan Studies, 2016 (04): 45-54. 